John Carroll University

Carroll Collected

$2-2019$

Analyzing the impact of workers' remittances on household consumption in Latin American and Caribbean Countries

Harri Ramcharran

Follow this and additional works at: https://collected.jcu.edu/fac_bib_2019

Part of the Business Commons 


\title{
Analyzing the impact of workers' remittances on household consumption in Latin American and Caribbean Countries
}

\author{
Harri Ramcharran
}

\begin{abstract}
Increasing remittance flows to developing countries continue to stimulate analytical research. We apply a model, based on the "permanent income hypothesis", to estimate the impact of remittances on consumption in eleven Latin American and Caribbean countries for the period of 2003-2013. The independent variables are: (a) real per capita national income (exclusive of remittances), the measure of "permanent income", (b) remittances, the measure of "transitory income", and (c) real interest rate, the indicator of intertemporal consumption substitution. The coefficient of remittances measures the consumption-augmentation and saving effects, while the correlation between remittances and per capita income indicates the consumption-smoothing effects. The results, based on the panel data methodology, indicate: (a) both permanent income and transitory income positively impact consumption, (b) consumption responds higher to permanent income than to transitory income, (c) transitory income has augmenting, stabilizing and countercyclical effects on consumption, and (d) the significant interest rate indicates the ability of recipients to make intertemporal consumption substitution. Evidence of significant "country effect" attests to heterogeneity among countries. Strategies to stabilize remittance flows and to leverage them for financial, economic and social development should be important policy considerations.
\end{abstract}

\section{Keywords}

Remittances $\cdot$ Transitory income $\cdot$ Permanent income $\cdot$ Consumption smoothing

Harri Ramcharran

hramcharran@jcu.edu

Department of Economics and Finance, John Carroll University, University Heights, $\mathrm{OH} 44118$, USA 


\section{Introduction}

The impact of remittance flows on the economy of recipient countries continues to stimulate current research, for example, Grigorian and Kryshko (2017), Barajas et al. (2009), Fajnzylber and Humberto-Lopez (2008), and Goldberg and Levi (2008). ${ }^{1}$ Recent studies focus on several issues: (i) Gabriela-Mundaca (2009) on economic growth, (ii) UNCTAD (2011) and Adams and Page (2005) on the poverty level (iii) Aggarwal and Demirguc-Kunt (2006) on financial sector development, (iv) Lueth and Ruiz-Arranz (2006) on the determinants of flows, (v) Neagu and Schiff (2009) on the stability, cyclicality and stabilizing impact, and (vi) Yang (2006) and Yang and Choi (2007) on consumption smoothing. ${ }^{2}$ A topical issue is the impact of remittances on consumption, specifically as related to consumption augmentation, smoothing and volatility, and the potential Keynesian multiplier effect on the economy. The World Bank (2015) has examined ways that remittances can help promote consumption stability. In recent several countries have implemented economic liberalization policies that inter alia, target consumption driven growth.

Previous studies, World Bank (2006a) and Adams (2006), are supportive of the consumption-increasing and poverty- reduction effects of remittances, these results, however, are based on survey data and the analysis of descriptive statistics. We extend the literature by using amore analytical methodology. We empirically estimating a consumption behavior model specified within the framework of the "permanent income hypothesis" (PIH), originally articulated by Friedman (1957) and Modigliani (1976), to analyze the impact of remittances on consumption pattern in eleven Latin American and Caribbean (LAC) countries for the period 2003-2013. The PIH relates consumption to permanent and transitory income. The theoretical model is justified on the basis of several analytical studies of the PIH, some include Willassen (1978), Hall and Mishkin (1982) and Kreuger and Perri (2008). They have applied (and tested the validity of) the PIH to analyze consumption behavior using different measurement of income (transitory and permanent).

We use several panel data models (Restricted, Unrestricted-Fixed Effects, Fixed Effects and Random Effects) and perform diagnostic tests to validate the results. The independent variables are: (i) real per capita national income (exclusive of remittances) as the measurement of "permanent income", (ii) remittances as "transitory income" and (iii) real interest rate (the opportunity cost of money). We justify the use of these variables within the framework of the PIH later in the paper. The interpretation of the results is as follows: (i) the coefficient of remittances (transitory income) measures the consumption augmentation and saving effects; (ii) the correlation between remittances (transitory income) and real per capita income (permanent income) indicates the cyclical effect; a low (or negative) correlation is considered counter cyclical and a positive (or high) correlation pro-cyclical; also a negative correlation is indicative of the

\footnotetext{
${ }^{1}$ Migrant remittances are defined as the sum of workers' remittances, compensation of employees, and migrants' transfers. Workers' remittances, as defined by the International Monetary Fund (IMF) in the Balance of Payments Manual, 6th edition (IMF 2010), are current private transfers from migrant workers who are considered residents of the host country to recipients in the workers' country of origin.

${ }^{2}$ The Multilateral Investment Fund (2006) also lists the following potential impact of remittances on the regional economy of Latin America and Caribbean; (i) insurance investments, (ii) banking investments, (iii) housing investments, (iv) educational investments, (v) microfinance institution loans, (vi) direct payments, and (vii) agriculture credits.
} 
consumption smoothing effect of remittances, and (iii) the significance of real interest rate indicates the ability of households (recipients) to make intertemporal substitution in consumption through savings and the accumulation of assets.

We use data for the period 2003-2013 for eleven Latin American and Caribbean (LAC) countries Colombia, Costa Rica, Ecuador, Mexico, El Salvador, Guatemala, Honduras, Dominican Republic, Jamaica, Nicaragua, and Panama. The choice of these countries is based on several factors: (a) International Migration Outlook(OECD 2006) lists them as the largest recipients of remittances in the region, and (b) the relevant data are available for them, unlike some other countries of the region. The choice of the period has to do with the availability of published data on a country basis (a) the World Bank began publishing data in the early 2000 and on a country basis in 2003 (see Migration and Remittances Fact Book 2011); (b) the latest edition (Migration and Development Brief, World Bank 2015) and Migration and Remittances Factbook (World Bank 2006a, b) have only preliminary estimates of remittances for 2014 and 2015; and (c) International Financial Statistics (IMF 2015), has many recent data missing on exchange rates, inflation rates, and interest rate for some countries. These countries constitute a group with different levels of GDP, consumption, population, and remittances Appendix Table 3 provides important ratios on consumption/GDP, per capita GDP, per capita remittances, and remittances/GDP over the same period. The high consumption/GDP and remittance/GDP ratios justify the importance of this study. Remittance flows to developing countries continue to increase after the current global recession; officially recorded flows are estimated to have reached $\$ 430$ billion in 2014, an increase of 3.2\% over 2013 (see Appendix Table 4). Flows to LAC countries reached $\$ 64$ billion in 2014, this amount comprises about $15 \%$ of total flows to developing countries. The LAC region receives over $75 \%$ of its remittances from the United States, thus these flows are susceptible to USA economic cycle and regulatory policies.

The findings of this study have important policy ramifications regarding consumption stability and the leveraging of remittances to improve the economic and social development of recipient countries. This is consistent with the achievement of the Sustainable Development Goals (United Nations 2015) of eradicating extreme poverty and hunger. The Economic Commission for Latin America and the Caribbean (2014) notes that in recent years an increase in household income in the region has resulted in a striking rise in consumption, however, the consumption pattern is strongly pro-cyclical and volatile; this has exposed the economies of the region to greater vulnerability. There are also significant concerns regarding the volatility (risk factors) affecting remittance flows to the region: (a) the economic crisis in the USA had a dampening impact on migrants' income, prompting them to decrease the frequency of their transfers, and (b) regulatory factors, for example, current immigration reform policies enacted by the Trump administration that could impact the number of immigrants from LAC in USA. ${ }^{3}$

The rest of the paper includes the following: Section 2 reviews of the literature on the PIH; Section 3 analyzes the recent trend in remittance flows; Section 4 discusses the impact of remittances, economic, and consumption; Section 5 discusses the data and the statistical properties; Section 6 discusses the specification of the model; Section 7 discusses the empirical results and the ramifications; Section 8 provides the conclusion.

\footnotetext{
3 They also sent less money per transfer as noted by the Inter-American Development Bank (2009). Remittances from Spain showed average transaction value that were 6\% lower than 2008.
} 


\section{Relevant literature: Permanent income hypothesis}

\subsection{Permanent income hypothesis}

This paper encompasses a large literature (originally articulated by Friedman 1957 and Modigliani 1976) on the determinants of household consumption. The main independent variables of these studies include: (i) current income, (ii) expected future income, (iii) wealth, and (iv) interest rate. The PIH assumes that consumers: (i) prefer a smooth pattern of consumption, (ii) are farsighted and have a clear vision (no uncertainty) about future income, and (iii) are able to borrow. On the basis of this set of assumptions, they are able to maximize "lifetime" or permanent consumption. According to the PIH, the observed value of consumers income $\left(\mathrm{Y}^{\mathrm{O}}\right)$ comprises two components, permanent income $\left(\mathrm{Y}^{\mathrm{P}}\right)$ and transitory income $\left(\mathrm{Y}^{\mathrm{T}}\right)$; $\mathrm{Y}^{\mathrm{P}}$ includes current income plus expected income from various forms of assets, $\mathrm{Y}^{\mathrm{T}}$ is windfall gains measured by $\left(\mathrm{Y}^{\mathrm{O}}-\mathrm{Y}^{\mathrm{P}}\right)$. Consumers form an estimate of $\mathrm{Y}^{\mathrm{P}}$ and assign an appropriate fraction for consumption; $\mathrm{Y}^{\mathrm{T}}$ does not affect consumption since its expected value equals zero; also $\mathrm{Y}^{\mathrm{T}}$ and $\mathrm{Y}^{\mathrm{P}}$ are uncorrelated. The life cycle hypothesis ( $\mathrm{LCH}$ ) is partly built on the PIH and focuses on consumption planning over life time, i.e. the choice between current consumption and future consumption. If consumers' current income $\left(\mathrm{Y}^{\mathrm{C}}\right)$ is relatively higher $\left(\mathrm{Y}^{\mathrm{C}}>\mathrm{Y}^{\mathrm{P}}\right)$, there is saving to be used for future consumption; borrowing occurs if $\left(\mathrm{Y}^{\mathrm{C}}<\mathrm{Y}^{\mathrm{P}}\right)$ thus consumption smoothing takes place through borrowing and saving which are determined by the real interest rate.

A topical area of research is the role of transitory income on consumption based on the PIH which assumes that transitory income is "windfall gains" (the random variation from average income) and is non-correlated with consumption. ${ }^{4}$ Earlier studies, Doenges (1966) and Kreinin (1961), examine the marginal propensity to consume (MPC) between transitory income and permanent income, they have arrived at different conclusions. Other studies articulate the rationale for a positive MPC of transitory income; Willassen (1978) argues that if the "windfall gains" (transitory income according to PIH) are anticipated, they should be incorporated in recipients' budget plans and should not be regarded as a random variable. A common problem with these studies is how to estimate or separate the transitory component of income. Hall and Mishkin (1982) examine the sensitivity of food consumption to transitory-income; they report the significance of transitory income measured by a stochastic component of real lifetime income. Their major findings are: (i) consumption responds much more strongly to permanent rather than to transitory movement in income, (ii) the response to transitory income is vigorous if the interest rate is included in the model, and (iii) a rejection of the pure life-cycle/PIH hypothesis.

\subsection{Empirical studies of the PIH}

Several studies, including Laumas (1969) and Holmes (1974), have documented the measurement of $\mathrm{Y}^{\mathrm{P}}$ and $\mathrm{Y}^{\mathrm{T}}$ as a significant problem in the empirical estimation of the

\footnotetext{
${ }^{4}$ The PIH postulates the following: (i) non-correlation between the transitory and permanent component of income, (ii) non-correlation between transitory consumption and permanent consumption, (iii) non-correlation between transitory consumption and transitory income.
} 
PIH. Hall (1978, page 971) notes "the major problem in empirical research based on the hypothesis has arisen in fitting the part of the model that relates current and past observed income to expected future income;" additionally, (page 972) "much empirical research is seriously weakened by failing to take proper account of the endogeneity of income when it is the major independent variable in the consumption function." Lucas (1976) argues that there is no theoretical reason for expectations formed by reasonably intelligent economic agents about future variables to be adequately explained by past data in a stable manner. Carlin and Soskice (2005) contend that it is necessary to relax some of the assumptions of the PIH in order to account for the empirical behavior of consumers' expenditures because of the uncertainty about future income and the limited access that some households have to financial markets. The conventional practice in the literature, as noted by Hayashi (1982), has been to proxy permanent income by current or past disposable income. Hall and Mishkin (1982) and Kreuger and Perri (2008) use values for $\mathrm{Y}^{\mathrm{P}}$ and $\mathrm{Y}^{\mathrm{T}}$ that are different from those discussed in the theoretical PIH.

Our methodology contributes to the current empirical literature by analyzing different sources of income flows that could be clearly classified as $\mathrm{Y}^{\mathrm{P}}$ (real per capita income exclusive of remittances) and $\mathrm{Y}^{\mathrm{T}}$ (remittance flows) and theoretically justified. The impact of real interest rate which allows for saving and borrowing, a la the Life Cycle Hypothesis (Modigliani 1976) is also examined since it enables an examination of the consumption smoothing effect. The World Bank ( 2006a, b, p.125) notes that remittances are viewed by households as transitory income rather than permanent and should be saved rather than currently spent. The results of this study also enable us to test the validity of this argument. One limitation of the model is that it is applied to countries with inadequate published data on consumers' ownership of different forms of assets (wealth) and imperfect financial and labor markets.

\section{Recent trend in remittance flows}

Appendix Table 4 shows that since the recent global financial crisis, remittance flows to all six developing regions begin to increase although the growth rate for each region varies. ${ }^{5}$ Total remittance flows to all developing countries are estimated to have reached $\$ 430$ billion in 2014, up $4 \%$ over 2013. UNCTAD (2011) also reports that remittances through informal channels could add at least $50 \%$ more to the recorded official flows. India, China, and Mexico were the top recipients in 2011 in terms of billions of dollars; however, there are other countries with high remittances/GDP, for example, Tajikistan (31\%), Guyana (22\%), Haiti (21\%), and El Salvador (16\%). The US is the largest source of remittances, followed by the Russian Federation, Saudi Arabia and Switzerland. The largest group of remitters has been US-residing Latin Americas with a disproportionate share going to Mexico.

\footnotetext{
5 There are several factors that affect the amount of remittance flows: (i) economic conditions in migrant destination countries (host countries), (ii) migrant population and migrant unemployment rate in host countries, (iii) the average wage rate for migrant workers in host countries, (iv) the level of family needs in recipient countries, (v) the economic conditions in recipient countries which affect needs and possibility for out migration, and (vi) remittance transfer costs.
} 
There are several factors that have positively impacted remittance flows: and (i) increased immigration to developed countries; (ii) international agreement to decrease the cost of transferring remittance, ${ }^{6}$ (iii) high oil prices once generated an increase in remittance flows from Russia to Central Asia, and from the Gulf region to South and Southeast Asia, and (iv) currency changes and inflation rates in some recipient countries. Many studies note financial markets reform as an incentive for sending remittances; Grigorian and Kryshko (2017) mention that the availability of deposit insurance encourages the use of formal channels for transmitting remittances. The impact of the global financial crisis varies from region to region depending on the regional diversification of the sources of remittances (IMF 2009). Policies to enable remittance flows to absorb macroeconomic shocks are crucial. Several studies (Barajas et al. 2010) have analyzed the risk/volatility of remittance flows and its economic impact.

\section{The impact of remittances}

\subsection{Economic impact}

The importance of remittances is well documented in the literature; the focus is on the household and the economy. The impact on growth depends on the motives for remitting; according to Chami et al. (2005) the non-profit motive (humanistic) depresses growth, while the profit driven motive increases growth. Importantly, Goldberg and Levi (2008) notes that the remittances/GDP ratio a measure of the growth effect) tend to vary significantly among the largest recipients. Several studies, including Faini (2002), Ekanayake and Mihalis (2008) and Spatafora (2005) examine the linkages between remittances, trade, consumption, investment and economic growth, and they obtain mixed results. Aggarwal and DemirgucKunt (2006) report that remittances also contribute to considerable financial deepening due to an increase in deposits and credits in the local banking industry. Many studies (Yang 2004, Mishra 2007, and Acosta et al. 2008) note a negative relationship between remittance flows and the labor force participation rate, however this may allow recipients to engage in other productive domestic household activities.

Two major studies examine the impact of remittances on output shocks, a phenomenon known as risk sharing (income smoothing). Balli and Rana (2015) find that remittances provide insurance against domestic output in eighty-six developing countries over the period 1990-2010. Balli et al. (2013) also report that the less developed (non-oil) Middle Eastern and North African (MENA) countries experience substantial income smoothing from remittances, unlike the oil rich Gulf countries.

\subsection{Remittances and consumption}

By increasing the income of recipients, remittances can lead to changes in savings, expenditure patterns, and household behavior. There are several factors that impact the

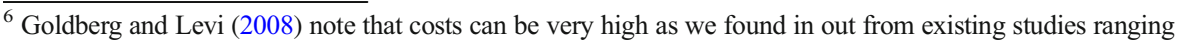
from $10 \%$ to $12 \%$ + depending on the amount transferred and the transfer agent. The Inter-American Development Bank (2009), dealing with remittances from the US to Latin America showed that the cost of remitting funds had dropped sharply to US $\$ 16.32$ for a US $\$ 200$ transfer in the summer of 2002 , just over half of what it was three years earlier.
} 
pattern of expenditure (propensity to consume, save and invest): (a) the level of income and social-economic background, and (b) location, (urban-rural). The result of a comparative study indicates that recipients from low income groups have a higher marginal propensity to save than non-recipients. Another survey shows that different income groups in different countries (and regions, urban-rural) spend different portion of remittances on food, non-durables, durables, housing, education, and health. Several studies are supportive of the impact of remittances on consumption augmentation and smoothing. We contend that a negative correlation between remittances and real per capita income is counter cyclical, that it, remittance flows increase during economic slowdown, in recipient countries. This tends to have a consumption smoothing effect. UNCTAD (2010) notes the following: (i) expenditures on household consumption represent about $70 \%$ of the amount transferred; (ii) remittances make up over $50 \%$ of recipients' total household income, and (iii) a positive multiplier effect on the economy because of the consumption of locally produced goods.

Maximizing the benefits of remittances by household entails a risk minimizing strategy because of the volatility in the factors affecting the determinants of remittance flows. Acosta et al. (2008) list two important risk reduction strategies: (i) the ex-ante risk coping mechanism, necessitating part of remittances to be saved and sources of income must be diversified to enable consumption smoothing; and (ii) the ex-post reaction to negative shocks, or the counter-cyclicality of remittance flows, necessitating recipients may request migrants to increase remittances in recession period or encourage the emigration of other family members.

\subsection{Remittances, consumption and growth in LAC}

Remittance flows to LAC countries increase steadily from 2001 (\$21.9 bil. US) to 2008 ( $\$ 64.3$ bil. US); they decrease to $\$ 56.5$ bil. in 2009 the peak of the economic crisis in the USA then increases slowly to $\$ 61.3$ bil. in 2013 . Flows to LAC countries as a percentage of flows to all developing countries decrease from $19.75 \%$ in 2008 to $14.59 \%$ in 2013.

Studies of the LAC region focus on several issues: (i) Adams (2006) report that recipients in Guatemala tend to spend a lower share of total remittances on food and other non-durables, and more on housing, education, and health, (ii) Gonzalez (2009) finds positive impact of remittance flows on the balance of payments and economic growth; Adelman and Taylor (1992) reports a positive relationship between remittances and growth in Mexico, (iii) Adams and Page (2005) finds a positive relationship between consumption and remittances in Guatemala, and (iv) Anzoategui and Demirguc-Kunt (2011), examining financial inclusion, reports a positive impact of remittances in promoting the use of deposit accounts in El Salvador. Importantly, Fajnzylber and HumbertoLopez (2008) report the following: (i) for every percentage point increase in the remittances /GDP ratio, the fraction of the population living in poverty is reduced by an average of about $0.4 \%$, and (ii) a one percentage point increase in remittances results in an approximately $2-3$ percentage point rise in bank deposits and credit.

\subsection{Remittances, consumption, and volatility}

A recent study in Global Economic Prospects (World Bank 2015) uses an econometric model to estimate the impact of remittances on the volatility in economic growth and 
consumption. The dependent variable is country-specific consumption growth and the independent variables are (i) country GDP growth and (ii) remittances/GDP ratio. A negative coefficient for the remittances/GDP ratio indicates the extent to which remittances help lower the volatility in country-specific consumption and output growth. The results show negative coefficients (of different magnitude) for all the regions studied, indicating that remittances have reduced the volatility in consumption and growth. Despite the rigor of this model, there are two possible concerns: (i) whether the measurement of GDP already includes remittances, and (ii) the possible multicollinearity between the two independent variables since both have GDP. The virtue of our methodology is that the impact of remittances on consumption and volatility is examined separately.

\section{Data and distributional properties}

The main sources of the data are (i) Migration and Remittances Factbook (World Bank 2011), Migration and Development Brief, World Bank, 2015, (ii) International Financial Statistics Yearbook (International Monetary Fund 2015), International Debt Statistics (World Bank, 2014). Real per capita national income (PCGNI) is derived from deflating Gross National Income (GNI) by population and the GDP deflator $(2005=100)$. GNI is GDP less primary income from abroad, this lends to the accuracy of separating transitory income (remittances) from permanent income (PCGNI). CON is per capita household consumption expenditures deflated by the CPI $(2005=100)$. REMIT is remittance flows. INT is real long term interest. PCGNI, CON and REMIT are measured in US\$ millions, this avoids any possible problem associated with the impact of exchange rate changes on the values of the estimates, and also help enable us to make cross-country comparison in consumption and purchasing power. It is important to note that the value of remittances used in this study are from official sources. Many studies have documented the presence of an informal channel for remittances, these flows are not tabulated nor included in national income data. The results of this study must be interpreted in terms of the official data used.

The distributional properties of the data on Appendix Table 5, in most cases, show the absence of normality (an important assumption of data distribution in econometrics). To minimize this problem, we test for the stability of the data using two panel-based unit root tests, (i) Levin et al. (2002), and (ii) Breitung (2000). Based on the results (Appendix Table 6), the null hypothesis of the Group Unit Root Test is rejected at the first difference and second difference levels for the three categories (a) with individual intercept, (b) with trend and intercept, and (c) none.

\section{Model specification}

We use the panel data methodology (Baltagi 2002) with the estimation of four different model specifications: (a) Restricted, (b) Unrestricted-Fixed Effects, (c) Fixed Effects, and (d) Random Effects. We use different diagnostic tests to determine the relevant specification. The model specified relates real consumption $(\mathrm{CON})$ as a function of three independent variables (i) the real interest rate (INT), (ii) Remittances (REMIT), and (iii) real per capita national income (PCGNI). Based on the theoretical PIH model, REM is the measurement of transitory income and PCGNI is the measurement of 
permanent income. A positive relationship is hypothesized between CON and PCGNI, and between CON and REMIT (the consumption augmentation effect), while a negative relationship between CON and INT. A decrease in INT encourages current consumption (by borrowing) while an increase in INT motivates savings (less current consumption) a la the inter-temporal choice theory (the ability of household to substitute between current and future consumption).

\subsection{Restricted model}

We specify the model in double logarithmic format: (a) to minimize the impact of the extreme values (outliers) of some variables on the regression estimates, and (b) each estimated coefficient is interpreted as elasticity of the independent variable with respect to dependent variable. Eq. 1 indicates the pooled constant coefficient model.

$$
\begin{gathered}
\ln \mathrm{CON}_{\text {it }}=\mathrm{a}_{1}+\mathrm{a}_{2} \ln \mathrm{INT}_{\text {it }}+\mathrm{a}_{3} \ln \mathrm{REMIT}_{\text {it }}+\mathrm{a}_{4} \ln \mathrm{PCGNI}_{\mathrm{it}}+\mu_{\text {it }} \\
\mathrm{i}=1-11 ; \mathrm{t}=2003-2013
\end{gathered}
$$

If the results show: (i) high $\mathrm{t}$ values, (ii) high $\mathrm{R}^{2}$, (iii) the expected sign of each coefficient, and (iv) low DW statistic, then there is evidence of auto-correlation or spatial correlation. This model does not take care of heterogeneity or individual uniqueness of each country since the constant intercept coefficient $\left(a_{1}\right)$ is the same for each country. Individuality is the subject of the error term; auto-correlation could be caused by heterogeneity, which is unobservable data.

\subsection{Unrestricted model: LSDV fixed effects}

The Least Squares Dummy Variable (LSDV) model allows for heterogeneity among countries by allowing each entity to have its own intercept value. In this model (i) intercepts are different for each entity but do not vary over time (time invariant), (ii) the slope coefficient of the regressor does not vary across countries over time. It is specified as Eq. 2.

$$
\begin{gathered}
\ln \mathrm{CON}_{\text {it }}=\mathrm{a}_{1 \mathrm{i}}+\mathrm{a}_{2} \ln \mathrm{INT}_{\text {it }}+\mathrm{a}_{3} \ln \mathrm{REMIT}_{\mathrm{it}}+\mathrm{a}_{4} \ln \mathrm{PCGNI}_{\mathrm{it}}+\mu_{\mathrm{it}} \\
\mathrm{i}=1-11 ; \mathrm{t}=2003-2013
\end{gathered}
$$

Note that there is a subscript $i$ on the intercept term to suggest that the intercepts of the 11 countries may be different. The difference may be due to heterogeneity caused by cultural, institutional and economic factors.

Country effect The LSDV-FE model allows for heterogeneity by estimating a different intercept for each country. The model is specified without the constant term because it is not necessary to identify a base (reference) country to make comparison. We estimate Eq. 2 with 11 dummies to represent the 11 countries.

Time effect The restricted model imposes a common intercept for the entire period, i.e. it is time- invariant. For risk and changing policy considerations/effects it is important to detect the timely (dynamic) effects of remittances on consumption over time. We estimate Eq. 2 with an intercept term and ten (2004-2013) time dummies; the intercept coefficient represents the value of the base (reference) period 2003. The dummy variable co-efficient 
measures the yearly change in the intercept in the post 2003 period due to changes in remittances. The intercept differential represents the structural shifts are due to regulatory or external factors; in this case, economic recession, unemployment in the housing/ construction sector and border patrol in the USA.

We use the "one way" fixed effects model, since the "two way" model which incorporates dummies for both time and country effects lead to the problems of inadequate degree of freedom and avoid the dummy variable trap, a situation where perfect collinearity (or multicollinearity) may exist (Gujarati and Porter 2009).

\subsection{The fixed effects model (FEM)}

An extension of the LSDV-FE model is the FEM which is estimated without the "time" dummies and the "country' dummies. The different intercept estimates of the FE-LSDV model are captured by the intercept (constant) estimate of the FEM; it is referred to as the "average fixed effects".

\subsection{The random effects model (REM)}

Kmenta (1986) provides the rationale for the REM; if the dummy variables do in fact represent a lack of knowledge about the true model why not express this ignorance through the disturbance term. It is important to discuss the differences between the FEM and the REM. (a) in the FEM, each unit has its own (fixed) intercept coefficient; in the REM, the intercept values are random, thus we observe fixed individual effects and random individual effects; (b) in the REM, the error term is composite with: (i) a crosssection of individual specific error component, and (ii) a component that combines time series and cross-section error, called the idiosyncratic term because it varies over crosssection units as well as time; (c) for the REM, the assumption is that the individual error components are not correlated with each other and are not auto-correlated across both cross sections and time series unit; (d) the REM is specifically estimated using the GLS technique; (e) unlike the fixed effects estimators, the REM takes into account variation between individuals as well as variation within individuals, this makes it an attractive alternative to the fixed effects estimations; and (f) the Hausman (1998) test is used for comparing the results of the FEM and the REM regressions; the null hypothesis underlining the Hausman test is that the estimators do not differ substantially if it is rejected the conclusion is that the REM is not appropriate because the random effects are probably correlated with one or more regressors (Gujarati and Porter 2009, Ch. 16).

We thought also of using, the dynamic panel data approach by including the lagged LFPR value as an independent variable. However, there are several estimation problems associated with the dynamic panel data technique. First, there is a reduction in the degree of freedom. Second, we usually deal with unobserved heterogeneity in panel data regressions by using fixed or random effects models. In a dynamic panel data setting, these methods create a correlation between the lagged dependent variable and error term that makes the coefficient of the lagged dependent variable biased, especially when we have samples with a small time dimension like ours. The Arellano and Bond's (1991) GMM estimator is a commonly proposed solution to this problem but, as argued by Bond (2002), it 
is also likely to give us biased estimations when the available instruments are weak, which is frequently the case.

\section{Discussion of Results}

\subsection{Restricted model}

We estimate the model (panel least squares) with cluster-robust standard errors (White period standard errors and covariance); Carter-Hill et al. (2011) provide the justification for using this technique. The results, with t-values in parentheses, are:

$$
\begin{gathered}
\text { LCON }=-3.413170+0.733204 \text { LREMIT-0.167829 LINT }+1.011560 \text { LPCGNI } \\
(-5.1217)(18.8863)(-2.1697)(15.0718) \\
\mathrm{R}^{2}=0.831845 ; \mathrm{DW} \text { stat }=1.352814 ; \mathrm{F}-\text { statistic }=192.9283
\end{gathered}
$$

Each coefficient represents the elasticity of the respective independent variables. The coefficients of all three independent variables LREMIT (0.733), LINT (-0.16), and LPCGNI (1.011) are statistically significant $(\rho<0.10)$ with the expected signs. We refrain from discussing the implications of the results until we examine the results of the LSDV-FE model.

\subsection{The unrestricted model (LSDV-FE)}

Country effect The results, presented on Table 1, indicate the significance of all three independent variables with the expected sign at $\rho<0.01$. Also, all the country intercept (dummy variable) coefficients are positive and significant $(\rho<0.01)$ indicating the presence of individual (unique) heterogeneity. We examine the results of (a) the Wald Test, and (b) the F statistic test to determine whether the results of the restricted model or the unrestricted model (LSDV-FE) should be used. ${ }^{7}$ Based on the value (see Table 1) of $\chi^{2}$ (5238.5) and of the F-statistic (476.22), we reject the null hypothesis $(\rho<0.01)$ of equal intercept; thus the LSDV-FE model is appropriate.

Time effect The estimates of the LSDV-FE model are presented on Table 2. The coefficient estimates of the independent variables of the LSDV-FE time effect are slightly different from those of the country effect (Table 1); however, the coefficients have the same signs, thus the interpretation and the implications of the results are the same. The intercept coefficient (-3.854) for the base period 2003 is statistically significant, however, the other yearly dummies (annual changes in the intercept) are negative, with the coefficients for the period 2008-2013 statistically significant. Based on the Wald test, the null hypothesis of the equal intercept is not rejected.

\footnotetext{
${ }^{7}$ Wald test and $\mathbf{F}$ test. If the intercepts are equal for all countries, then there are no fixed effect, that is no individual heterogeneity to be captured by these effects. We can test for the equality of all tests using the Wald Test. If the Null Hypothesis of equal intercepts is rejected, there are fixed effects that is individual heterogeneity can be captured by these effects.
} 
Table 1 Regression results: Unrestricted model: LSDV-FE, country effects

\begin{tabular}{|c|c|c|c|}
\hline \multicolumn{4}{|l|}{ Dependent variable: $\mathrm{Ln}$ CON } \\
\hline \multicolumn{4}{|l|}{ Method: Panel least squares } \\
\hline \multicolumn{4}{|c|}{ Total panel (unbalanced) observations: 121} \\
\hline Variable & & Coefficient & t-Statistic \\
\hline Ln LREMIT & & 0.161891 & 3.816105 \\
\hline Ln LINT & & -0.099235 & -3.704949 \\
\hline Ln LPCGNI & & 0.875797 & 8.70739 \\
\hline DUM $_{\text {COLOMBIA }}$ & & 3.267934 & 10.05961 \\
\hline DUM $_{\text {COSTARICA }}$ & & 1.413167 & 4.311360 \\
\hline DUM $_{\text {DOMINICAN REPUBLIC }}$ & & 2.069431 & 6.346274 \\
\hline DUM $_{\text {ECUADOR }}$ & & 2.098978 & 6.761616 \\
\hline DUM $_{\text {ELSALVADOR }}$ & & 1.586239 & 5.202213 \\
\hline DUM $_{\text {GUATEMALA }}$ & & 2.311717 & 7.535622 \\
\hline DUM $_{\text {HONDURAS }}$ & & 1.707714 & 5.662951 \\
\hline DUM $_{\text {JAMAICA }}$ & & 0.852340 & 2.681467 \\
\hline DUM $_{\text {MEXICO }}$ & & 3.903848 & 11.27825 \\
\hline DUM $_{\text {NICARAGUA }}$ & & 1.433979 & 5.386951 \\
\hline DUM $_{\text {PANAMA }}$ & & 1.010616 & 3.165846 \\
\hline $\mathrm{R}^{2}$ & & 0.896117 & \\
\hline Adjusted $\mathrm{R}^{2}$ & & 0.895645 & \\
\hline Durbin-Watson stat & & 0.104957 & \\
\hline \multicolumn{4}{|l|}{ Wald test: country effect } \\
\hline Test Statistic & Value & df & Probability \\
\hline F-statistic & 476.2297 & $(11,107)$ & 0.00000 \\
\hline Chi-square & 5238.527 & 11 & 0.00000 \\
\hline
\end{tabular}

\subsection{The FEM and REM}

The coefficient estimates, with the t-values in parentheses, of the FEM (panel least squares) and the REM (panel EGLS using Swamy and Arora estimator of component variances) are:

\section{$\underline{\text { Fixed Effects Model }}$}

$$
\begin{aligned}
& \text { LCON }=-3.4132+0.7332 \text { LREMIT-0.1678 LINT }+1.0116 \text { LPCGNI } \\
& \begin{array}{llll}
(-4.2388) & (6.731) \quad(-1.8283) & (11.4912)
\end{array} \\
& \mathrm{R}^{2}=0.8318 ; \mathrm{DW} \text { stat }=1.3528 ; \mathrm{F}-\text { statistic }=192.9283
\end{aligned}
$$

\section{$\underline{\text { Random Effects Model }}$}

$$
\begin{gathered}
\text { LCON }=-11.7246+0.7047 \text { LREMIT }-0.8775 \text { LINT + 1.8512 LPCGNI } \\
(-3.4439) \quad(6.5235) \quad(-3.1298) \quad(12.2564) \\
\mathrm{R}^{2}=0.983 ; \mathrm{DW} \text { stat }=2.34 ; \mathrm{F}-\text { statistic }=233.67
\end{gathered}
$$

Applying the Hausman Test (for correlated random effects or for cross-section random effects), the value of the $\chi^{2}$ statistic (182.83) with the associated $\rho(0.0000)$, we reject the null hypothesis and accept the results of the FEM. For the REM, the random effects are probably correlated with one or more regressors, (right hand side variables), a case of endogeneity. The signs and the significance of coefficients of the FEM are not significantly different from those of the other models. 
Table 2 Regression results of the unrestricted model: LSDV-FE time effects

\begin{tabular}{|c|c|c|c|}
\hline \multicolumn{4}{|c|}{ Dependent Variable: Ln CON } \\
\hline \multicolumn{4}{|c|}{ Method: Panel least squares } \\
\hline Variable & & Coefficient & $\mathrm{t}$-Statistic \\
\hline Constant & & -3.854678 & -4.706305 \\
\hline Ln LREMIT & & 0.148837 & 17.18245 \\
\hline Ln LINT & & -0.134014 & -2.439073 \\
\hline Ln LPCGNI & & 0.713657 & 12.16898 \\
\hline DUM $_{2004}$ & & -0.112222 & -0.484728 \\
\hline $\mathrm{DUM}_{2005}$ & & -0.288681 & -1.241927 \\
\hline $\mathrm{DUM}_{2006}$ & & -0.321605 & -1.381456 \\
\hline DUM $_{2007}$ & & -0.379385 & -1.622455 \\
\hline $\mathrm{DUM}_{2008}$ & & -0.561183 & -2.366707 \\
\hline $\mathrm{DUM}_{2009}$ & & -0.484287 & -2.052264 \\
\hline $\mathrm{DUM}_{2010}$ & & -0.539483 & -2.250398 \\
\hline DUM $_{2011}$ & & -0.583238 & -2.391570 \\
\hline $\mathrm{DUM}_{2012}$ & & -0.605654 & -2.477089 \\
\hline $\mathrm{DUM}_{2013}$ & & -0.643758 & -2.627377 \\
\hline $\mathrm{R}^{2}$ & & 0.850496 & \\
\hline Adjusted R² & & 0.832332 & \\
\hline Durbin-Watson stat & & 1.215657 & \\
\hline F-statistic & & 46.82303 & \\
\hline \multicolumn{4}{|l|}{ Wald Test: Time effect } \\
\hline Test Statistic & Value & $\mathrm{df}$ & Probability \\
\hline F-statistic & 1.334873 & $(10,107)$ & 0.2214 \\
\hline Chi-square & 13.34873 & 10 & 0.2048 \\
\hline
\end{tabular}

\subsection{The relevant model and discussion of the results}

Based on the diagnostic tests, the results of the FEM and LSDV-FE (country effect) models are considered relevant. The signs, values, and level of significance of the coefficients are very similar. We discuss the results of the LSDV model, presented on Table 1, since the significant dummy variable coefficients add further information regarding heterogeneity. All the coefficients are statistical significant at the $95 \%$ level with the hypothesized signs. The coefficient estimate $(-0.099)$ indicates a low response in consumption $(\mathrm{CON})$ to changes in of real interest rate (INT) or the ability of households to make inter-temporal choice between present and future consumption through borrowing/saving. This phenomenon is common in countries with undeveloped financial and capital markets and relatively inefficient financial institutions. The coefficient estimate $(0.8757)$ indicates a high per capita real national income (PCGNI) elasticity of consumption; this is supportive of the high consumption/GDP ratio reported on Table 3 . The coefficient estimate $(0.1618)$ attests to the importance of remittances (REMIT) on consumption with an elasticity of 0.17 (17\%), this is also supported by the high remittances/GDP ratio reported on Table 3; these ratios range from $1.23 \%$ to $19.23 \%$. The value of the remittance coefficient also indicates that a large part of remittances is saved; this finding partially supports the view that all of transitory income should be saved rather than spent on current consumption. UNCTAD (2010) reports a saving rate of $70 \%$ on remittances for countries in Asia and Africa. Households in countries with high level of poverty use remittances to smooth volatility in consumption as well as for savings/investment.

The coefficient of per capita real national income $(0.8757)$ is higher than that of remittances (0.1618), indicating that consumption responds more strongly to permanent income than to transitory income; similar to Hall and Mishkin (1982). Their findings, like 
ours, also do not support the PIH that transitory income does not impact consumption. The consumption smoothing effect of remittances is also indicated by the higher variability (standard deviation) in consumption (1.323) than in remittances (1.1768). The low correlation between remittances and per capita real national income $(0.2184)$ indicates the counter cyclical impact of remittances i.e. remittances increases when per capita real national income decreases (in the recipient countries), this finding supports the altruistic motive for remittances.

The value of the dummy variables (slope intercept) for each country is positive and statistically significant indicating that there is significant heterogeneity among the countries. The values range from 0.85 (Jamaica) to 3.9 (Mexico). The heterogeneity is attributed to differences in social and economic institutions, culture and attitude towards consumption, savings, and work. Several studies, using country specific micro-data (obtained from field study and survey techniques), identify many differences in social-economic characteristics that determine the use of remittances; for example, Adams (2006) notes that differences in social-economic behavior affect the propensity to consume, save and invest.

There are two important ramifications of the results. First, our results find a positive impact of remittances on consumption and also a stabilizing effect of remittances; they are different from Neagu and Schiff (2009) who find that remittance flows are pro-cyclical and have a destabilizing effect. Second, whether the positive contribution of remittances to consumption adds to the volatility of consumption in the LAC region (ECLAC 2014); we find a remittance (transitory income) elasticity of 0.167 , but a higher real national income (permanent income) elasticity of 0.875 . Based on these findings, we don't believe that remittances contribute to the volatility in consumption. Some policy makers are more concern about the negative effects of consumption volatility generated by increase in national income in the region rather than by remittance flows.

\section{Conclusion}

Based on the PIH, this study adds the literature on the impact of remittance flows on consumption behavior. The results indicate the significance of remittances (transitory income) as well as permanent income in selected LAC countries. The consumption augmentation and stabilization effects of remittances could contribute to savings, capital formation and investment in real and financial assets which could have a multiplier growth effect. The policy ramifications are: (a) global coordination to increase and stabilize the flow of remittances, and (b) institutional and financial reforms to enable the leveraging of remittances to enhance economic and social development (Ratha 2007). Policy makers in the region have to deal with many risk factors since about $75 \%$ of the flows to LAC countries originate from the USA; for example, (a) the Consumer Financial Protection Bureau (2011) rule which is designed to standardize the remittances industry as well as to promote transparency and disclosure in exchange rate and transfer cost, (b) the current immigration policy under the Trump administration could discourage emigration to the USA particularly from LAC countries, and (c) besides a decrease in consumption, other consequences of decreasing remittances include a loss in domestic banks' earnings from foreign exchange operations and the possible decline in credit to households and small firms.

Much of the studies on this topic use aggregate data. The availability of country specific micro-data on the uses of remittances could stimulate more elaborate studies. The minor 
limitation of this study is the unavailability of the most recently published data on other countries of the region with high remittances/GDP ratio (for example, Guyana and Haiti).

Acknowledgements I am very grateful to an anonymous reviewer for helpful comments/suggestions on earlier drafts of this paper. All errors are mine.

\section{Appendix}

Table 3 Important ratios (2003-2013)

\begin{tabular}{|c|c|c|c|c|c|c|c|c|}
\hline \multirow[b]{2}{*}{ Countries } & \multicolumn{2}{|c|}{ Con/GDP } & \multicolumn{2}{|c|}{ Remit/GDP } & \multicolumn{2}{|l|}{ Remit/Pop } & \multicolumn{2}{|l|}{ GDP/Pop } \\
\hline & Mean & St.Dev & Mean & St.Dev & Mean & St.Dev & Mean & St.Dev \\
\hline Colombia & $64.04 \%$ & 0.0242 & $1.90 \%$ & $0.54 \%$ & $\$ 87.6535$ & $\$ 10.1978$ & $10,482.8$ & 2727.4 \\
\hline Costa Rica & $66.14 \%$ & 0.0105 & $1.88 \%$ & $0.48 \%$ & $\$ 110.2109$ & $\$ 20.3729$ & $3,345,603.3$ & $1,155,694.1$ \\
\hline Dom Rep & $81.73 \%$ & 0.0480 & $8.24 \%$ & $0.60 \%$ & $\$ 345.9521$ & $\$ 62.5982$ & $157,060.2$ & $57,373.5$ \\
\hline Ecuador & $64.37 \%$ & 0.0345 & $4.78 \%$ & $1.42 \%$ & $\$ 184.2519$ & $\$ 38.2732$ & 3886.4 & 1264.5 \\
\hline El Salvador & $93.34 \%$ & 0.0256 & $17.70 \%$ & $1.69 \%$ & $\$ 546.3795$ & $\$ 87.3441$ & 3261.5 & 460.0 \\
\hline Guatemala & $86.65 \%$ & 0.0130 & $11.08 \%$ & $1.02 \%$ & $\$ 284.4449$ & $\$ 53.1965$ & $20,771.3$ & 4447.1 \\
\hline Hondras & $77.90 \%$ & 0.0264 & $19.32 \%$ & $1.74 \%$ & $\$ 312.5964$ & $\$ 85.9471$ & $34,392.3$ & 8457.2 \\
\hline Jamaica & $81.32 \%$ & 0.0487 & $16.62 \%$ & $1.16 \%$ & $\$ 671.9336$ & $\$ 159.7811$ & $334,823.2$ & $117,085.3$ \\
\hline Mexico & $66.07 \%$ & 0.0124 & $2.40 \%$ & $0.32 \%$ & $\$ 207.0754$ & $\$ 28.5274$ & 105.2 & 18.7 \\
\hline Nicaragua & $81.84 \%$ & 0.2432 & $9.73 \%$ & $0.75 \%$ & $\$ 135.3063$ & $\$ 30.3889$ & $33,024.9$ & $29,423.6$ \\
\hline Panama & $56.96 \%$ & 0.0546 & $1.23 \%$ & $0.31 \%$ & $\$ 86.4108$ & $\$ 33.0299$ & 7041.5 & 2512.7 \\
\hline
\end{tabular}

Con/GDP = Consumption/GDP; Remit/GDP = Remittance/GDP; Remit/Pop = Remittance/Population. (in US \$) GDP/Pop = per capita GDP in local currency except for Colombia and Mexico, which is in thousands of local currency Sources: International Financial Statistics Year book (IMF 2012 and 2016), International Debt Statistics (World Bank 2014), Migration and Remittances Factbook (World Bank 2011)

Table 4 Outlook for remittance flows to developing countries, 2008-2015

\begin{tabular}{lllllllll}
\hline & 2008 & 2009 & 2010 & 2011 & 2012 & 2013 & $2014 f$ & $2015 f$ \\
\hline \$ billions & & & & & & & & \\
All developing countries & $\mathbf{3 2 4}$ & $\mathbf{3 0 7}$ & $\mathbf{3 2 5}$ & $\mathbf{3 5 1}$ & $\mathbf{4 0 3}$ & $\mathbf{4 1 8}$ & $\mathbf{4 3 0}$ & $\mathbf{4 3 2}$ \\
$\quad$ East Asia and Pacific & 85 & 85 & 94 & 101 & 107 & 113 & 122 & 127 \\
Europe and Central Asia & 45 & 36 & 36 & 40 & 46 & 52 & 44 & 34 \\
Latin America and Caribbean & 64 & 57 & 57 & 61 & 60 & 61 & 64 & 67 \\
Middle-East and North Africa & 36 & 34 & 35 & 36 & 49 & 49 & 51 & 50 \\
South Asia & 72 & 75 & 82 & 90 & 108 & 111 & 116 & 118 \\
Sub-Saharan Africa & 22 & 20 & 21 & 23 & 32 & 32 & 35 & 35 \\
World & $\mathbf{4 5 6}$ & $\mathbf{4 2 9}$ & $\mathbf{4 4 9}$ & $\mathbf{4 8 3}$ & $\mathbf{5 3 3}$ & $\mathbf{5 5 7}$ & $\mathbf{5 9 2}$ & $\mathbf{5 8 2}$ \\
Low-income countries & 22 & 23 & 25 & 28 & 31 & 33 & 35 & 35 \\
Middle income & 302 & 284 & 301 & 324 & 372 & 385 & 401 & 405 \\
High income & 132 & 123 & 124 & 132 & 130 & 139 & 147.3 & 145.8 \\
Growth rate\% & & & & & & & & \\
All developing countries & $\mathbf{1 6 . 4}$ & $\mathbf{5 . 2}$ & $\mathbf{6}$ & $\mathbf{8}$ & $\mathbf{6 . 1}$ & $\mathbf{3 . 7}$ & $\mathbf{3 . 2}$ & $\mathbf{0 . 4}$ \\
East Asia and Pacific & 18.8 & 0.4 & 10.2 & 7.6 & 0.1 & 5.5 & 7.4 & 4.2 \\
Europe and Central Asia & 16.3 & 19.8 & -0.1 & 11 & 9.6 & 11.1 & -9.0 & -20.3 \\
Latin America and Caribbean & 2.2 & 12.2 & 1.2 & 7 & 1.1 & 1.2 & 4.0 & 4.8 \\
Middle-East and North Africa & 12 & -6.7 & 3.3 & 2.6 & 16 & 0 & 4.0 & -0.9 \\
South Asia & 32.6 & 4.8 & 9.5 & 10.1 & 11.2 & 2.5 & 4.3 & 2.0 \\
Sub-Saharan Africa & 15.8 & -7 & 4.5 & 7.1 & 1.6 & 0.9 & 0.2 & 1.0
\end{tabular}


Table 4 (continued)

\begin{tabular}{lllllllll}
\hline & 2008 & 2009 & 2010 & 2011 & 2012 & 2013 & $2014 \mathrm{f}$ & $2015 \mathrm{f}$ \\
\hline World & $\mathbf{1 5 . 9}$ & $\mathbf{- 5 . 8}$ & $\mathbf{4 . 6}$ & $\mathbf{7 . 5}$ & $\mathbf{4 . 1}$ & $\mathbf{4 . 5}$ & $\mathbf{3 . 3}$ & $\mathbf{- 1 . 7}$ \\
Low-income countries & 32.8 & 3.7 & 8.9 & 12 & 12.5 & 4.4 & 6.2 & 1.4 \\
Middle income & 15.4 & -5.9 & 5.8 & 7.6 & 5.6 & 3.6 & 4.2 & 0.9 \\
High income & 14.7 & -7.1 & 1.1 & 6.3 & -1.7 & 7.1 & 5.7 & -1
\end{tabular}

The bold entries indicate the total amount for the specific region

$\mathrm{f}=$ forecast

Sources

1. Migration and Development Brief \# 17, by Ratha et al. (2011)

2. Migration and Development Brief \# 24, by Ratha et al. (April 2015)

Table 5 Statistical properties of data (2003-2013)

\begin{tabular}{|c|c|c|c|c|c|c|c|}
\hline Countries & Stat Dist & Remit (US \$ Mil.) & Pop (Mil.) & Consumption & GDP & GNI in $\$$ & Interest Rate \\
\hline \multirow[t]{3}{*}{ Colombia } & Mean & 3956.73 & 45.05 & $302,765.55$ & $477,656.64$ & $230,332.14$ & 13.41 \\
\hline & St.Dev & 552.48 & 2.21 & $82,636.64$ & $146,318.30$ & $88,548.31$ & 2.31 \\
\hline & Kurtosis & -0.65 & -1.25 & -1.18 & -1.13 & -1.29 & -0.58 \\
\hline \multirow[t]{3}{*}{ Costa Rica } & Mean & 501.64 & 4.53 & $10,141,019.55$ & $15,390,836.55$ & $29,100.36$ & 19.17 \\
\hline & St.Dev & 105.30 & 0.23 & $3,830,875.45$ & $5,997,158.13$ & $11,636.43$ & 4.25 \\
\hline & Kurtosis & -0.27 & -1.15 & -1.26 & -1.22 & -1.03 & -1.28 \\
\hline Dominican & Mean & 3444.82 & 9.90 & $1,283,293.73$ & $1,573,932.27$ & $42,471.18$ & 19.88 \\
\hline \multirow[t]{2}{*}{ Republic } & St.Dev & 737.21 & 0.39 & $486,940.99$ & $623,341.44$ & $11,495.01$ & 6.83 \\
\hline & Kurtosis & -1.23 & -1.14 & -1.31 & -1.00 & -1.31 & 0.07 \\
\hline \multirow[t]{3}{*}{ Ecuador } & Mean & 2568.45 & 13.99 & $35,205.09$ & $55,581.18$ & $58,297.23$ & 11.59 \\
\hline & St.Dev & 498.34 & 1.13 & $12,674.66$ & $22,516.68$ & $20,307.49$ & 2.50 \\
\hline & Kurtosis & 0.27 & -1.62 & -1.02 & -0.77 & -0.98 & -2.46 \\
\hline \multirow[t]{3}{*}{ Elsalvador } & Mean & 3369.91 & 6.16 & $18,813.18$ & $20,121.17$ & $19,907.95$ & 7.02 \\
\hline & St.Dev & 576.31 & 0.11 & 3154.51 & 3160.86 & 2952.25 & 1.13 \\
\hline & Kurtosis & 0.94 & -1.14 & -0.97 & -1.07 & 0.29 & 0.06 \\
\hline \multirow[t]{3}{*}{ Guatemala } & Mean & 3948.18 & 13.72 & $250,864.00$ & $289,430.27$ & $36,214.00$ & 13.50 \\
\hline & St.Dev & 989.22 & 1.11 & $72,912.77$ & $84,313.70$ & $10,176.41$ & 0.61 \\
\hline & Kurtosis & -0.37 & -1.15 & -1.17 & -1.23 & -1.03 & 3.12 \\
\hline \multirow[t]{3}{*}{ Honduras } & Mean & 2323.73 & 7.34 & $201,004.64$ & $256,066.18$ & $12,203.18$ & 18.81 \\
\hline & St.Dev & 727.60 & 0.49 & $66,668.82$ & $78,989.49$ & 4258.26 & 1.22 \\
\hline & Kurtosis & 0.23 & -1.19 & -1.04 & -1.14 & -0.56 & -0.21 \\
\hline \multirow[t]{3}{*}{ Jamaica } & Mean & 1941.00 & 3.16 & $806,734.55$ & $979,718.09$ & $11,807.32$ & 17.98 \\
\hline & St.Dev & 254.11 & 1.52 & $275,049.21$ & $295,138.49$ & 2177.21 & 1.20 \\
\hline & Kurtosis & 0.52 & 10.97 & -1.32 & -1.29 & -0.07 & 0.43 \\
\hline \multirow[t]{3}{*}{ Mexico } & Mean & $23,018.09$ & 111.39 & 7826.00 & $11,831.17$ & $975,455.45$ & 6.75 \\
\hline & St.Dev & 3000.64 & 7.22 & 1927.57 & 2805.36 & $177,826.03$ & 1.74 \\
\hline & Kurtosis & 0.90 & -1.63 & -0.77 & -0.99 & -0.54 & -0.90 \\
\hline \multirow[t]{3}{*}{ Nicaragua } & Mean & 767.09 & 5.64 & $119,148.28$ & $185,250.90$ & 7819.45 & 13.07 \\
\hline & St.Dev & 196.41 & 0.31 & $57,107.41$ & $157,589.24$ & 1701.83 & 1.47 \\
\hline & Kurtosis & -0.48 & 0.40 & 0.05 & 6.60 & -1.03 & -0.27 \\
\hline \multirow[t]{3}{*}{ Panama } & Mean & 305.27 & 3.46 & $13,911.79$ & $24,971.96$ & $24,614.45$ & 8.06 \\
\hline & St.Dev & 128.43 & 0.26 & 5410.27 & $10,809.75$ & $10,339.80$ & 0.98 \\
\hline & Kurtosis & -0.98 & -1.51 & -1.06 & -0.65 & -0.98 & 0.04 \\
\hline
\end{tabular}

Remit $=$ Remittances in millions US $\$$. Pop $=$ Population in millions. Consumption = Consumption in millions of local currency, except for Colombia and Mexico, where it is in billions of local currency. GDP = Gross Domestic Product in millions of local currency except for Mexico and Colombia where it is in billions of local currency. GNI in \$ = Gross National Income in millions of US dollars. Interest Rate is the deposit rate

Sources: International Financial Statistics Year book (IMF 2012 and 2016), International Debt Statistics (World Bank 2014), Migration and Remittances Factbook (World Bank 2011) 
Table 6 Group Unit Root Test: Sample: 1121: Series: LCON, LINT, LREMIT, LPCGNI

\begin{tabular}{|c|c|c|c|c|}
\hline \multirow[t]{3}{*}{$\begin{array}{l}\text { Level (a) with individual } \\
\text { intercept }\end{array}$} & \multicolumn{3}{|c|}{ Null: Unit root (assumes common unit root) } & Obs \\
\hline & Levin, Lin \& Chu t & -1.61764 & 0.0529 & 480 \\
\hline & Breitung t-stat & -4.40351 & 0.0000 & 476 \\
\hline \multirow{4}{*}{$\begin{array}{l}\text { Level (b) with trend } \\
\text { and intercept }\end{array}$} & Method & Statistic & Prob. & Obs \\
\hline & \multicolumn{4}{|c|}{ Null: Unit root (assumes common unit root) } \\
\hline & Levin, Lin \& Chu t & -1.39294 & 0.0818 & 480 \\
\hline & Breitung t-stat & -0.17635 & 0.4300 & 476 \\
\hline \multirow[t]{4}{*}{ Level (c) none } & Method & Statistic & Prob. & Obs \\
\hline & \multicolumn{4}{|c|}{ Null: Unit root (assumes common unit root) } \\
\hline & Levin, Lin \& Chu t & -0.63727 & 0.2620 & 480 \\
\hline & Breitung t-stat & -1.05649 & 0.1454 & 476 \\
\hline \multirow{4}{*}{$\begin{array}{l}\text { 1st Diff(a) with individual } \\
\text { intercept }\end{array}$} & Method & Statistic & Prob. & Obs \\
\hline & \multicolumn{4}{|c|}{ Null: Unit root (assumes common unit root) } \\
\hline & Levin, Lin \& Chu t & -25.8214 & 0.0000 & 476 \\
\hline & Breitung t-stat & -19.7146 & 0.0000 & 472 \\
\hline \multirow{4}{*}{$\begin{array}{l}\text { 1st Diff (b) with trend } \\
\text { and intercept }\end{array}$} & Method & Statistic & Prob. & Obs \\
\hline & \multicolumn{4}{|c|}{ Null: Unit root (assumes common unit root) } \\
\hline & Levin, Lin \& Chu t & -28.947 & 0.0000 & 476 \\
\hline & Breitung t-stat & -18.8754 & 0.0000 & 472 \\
\hline \multirow[t]{4}{*}{ 1st Difference (c) none } & Method & Statistic & Prob. & Obs \\
\hline & \multicolumn{4}{|c|}{ Null: Unit root (assumes common unit root) } \\
\hline & Levin, Lin \& Chu t & -22.0583 & 0.0000 & 476 \\
\hline & Breitung t-stat & -21.2469 & 0.0000 & 472 \\
\hline \multirow{4}{*}{$\begin{array}{l}\text { 2nd Diff (a) with individual } \\
\text { intercept }\end{array}$} & Method & Statistic & Prob. & Obs \\
\hline & \multicolumn{4}{|c|}{ Null: Unit root (assumes common unit root) } \\
\hline & Levin, Lin \& Chu t & -10.7537 & 0.0000 & 455 \\
\hline & Breitung t-stat & -16.1546 & 0.0000 & 451 \\
\hline \multirow{4}{*}{$\begin{array}{l}\text { 2nd Diff (b) with trend } \\
\text { and intercept }\end{array}$} & Method & Statistic & Prob. & Obs \\
\hline & \multicolumn{4}{|c|}{ Null: Unit root (assumes common unit root) } \\
\hline & Levin, Lin \& Chu t & -10.8965 & 0.0000 & 455 \\
\hline & Breitung t-stat & -16.308 & 0.0000 & 451 \\
\hline \multirow[t]{4}{*}{ 2nd Diff (c) none } & Method & Statistic & Prob. & Obs \\
\hline & \multicolumn{4}{|c|}{ Null: Unit root (assumes common unit root) } \\
\hline & Levin, Lin \& Chu t & -17.6009 & 0.0000 & 455 \\
\hline & Breitung t-stat & -16.6025 & 0.0000 & 451 \\
\hline
\end{tabular}

\section{References}

Acosta P, Fajnzylber P, Humberto-Lopez J (2008) Remittances and household behavior: evidence for Latin America. In: Fajnzylber P, Humberto-Lopez J (eds) Remittances and development. World Bank

Adams R (2006), Remittances, Household Expenditure and Investment in Guatemala. Policy Research Working Paper 3532. World Bank, Washington. DC 
Adams R, Page J (2005) Do International migration and remittances reduce poverty in developing countries? World Dev 33:1645-1669

Adelman I, Taylor JE (1992) Is structural adjustment with a human face possible? J Dev Stud 26:387-487

Aggarwal R, Demirguc-Kunt M-P (2006) Do workers' remittances promote financial development? World Bank Policy Research Working Paper:3957

Anzoategui D, Demirguc-Kunt A (2011) Remittances and financial inclusion evidence from El Salvador, policy research working paper, \#5839. The World Bank

Arellano M, Bond S (1991) Some tests of specification for panel data: Monte Carlo evidence and an application to employment equations. Review of Economic Studies 58:277-297

Balli F, Rana F (2015) Determinant of risk sharing through remittances. J Bank Financ 55:107-116

Balli F, Basher SA, Louis RJ (2013) Risk sharing in the Middle East and North Africa. Econ Transit 21(1): $135-155$

Baltagi B (2002) Econometric Analysis of Panel Data, John Wiley and Sons, Ltd.

Barajas A, Chami R, Fullenkamp C, Gapen M, Montiel P (2009) Do workers' remittances promote economic growth? IMF Working Paper, (WP/09/153, July)

Barajas A, Chami R, Fullenkamp C, Garg A (2010), The global financial crisis and workers' remittances to Africa: what is the damage? IMF Working Paper, WP/10/24

Bond S (2002) Dynamic panel data models: a guide to micro data methods and practice. Port Econ J 1:141-162

Breitung J (2000) The local power of some unit root tests for panel data. In: Baltagi B (ed) Advances in econometrics, vol 15. JAI Press, Amsterdam, pp 161-178

Carlin W, Soskice D (2005) Macroeconomics: imperfections, institutions and policies. Oxford University Press, London

Carter-Hill R., Griffiths W E, Guay C L (2011) Principles of Ecoenometrics, Fourth Edition, J Wiley \& Sons, Inc.

Chami R, Fullenkamp C, Jahjah S (2005) Are immigrant remittance flows a source of capital for development? IMF Staff Paper 52(1):55-81

Consumer Financial Protection Bureau (2011) Report on remittance transfers July $20^{\text {th }}$

Doenges RC (1966) Transitory income size and saving. South Econ J 33(2):258-263

Economic Commission for Latin America and Caribbean (2014) Trends and risks of the consumption in Latin American and the Caribbean, (http://www.cepal.org)

Ekanayake EM, Mihalis H (2008) Do remittances and foreign direct investment promote growth? Evidence from developing countries. Journal of International Business and Economics, Jan-1

Faini R (2002) Development, Trade, and Migration, Revue d' Economie et du Developpement. Proceedings from the ABCDE Europe Conference, 1-2, pp. 85-116

Fajnzylber P, Humberto-Lopez J (2008) Remittance and development: lessons from Latin America, IBRD (World Bank)

Friedman M (1957) A Theory of the Consumption Function. Princeton Univ. Press, Princeton

Gabriela-Mundaca B (2009) Remittances, financial market development, and economic growth: the case of Latin America and the Caribbean. Rev Dev Econ 13(2):288-303. https://doi.org/10.1111/j.14679361.2008.00487.x

Global Economic Prospects (2015) Can remittances help promote consumption stability? World Bank; Washington, DC

Goldberg M, Levi M (2008) "The impact of remittances on economic growth" Mastercard worldwide,

Gonzalez ED (2009) The impact of remittances on macroeconomic stability: the cases of Mexico and Central America. CEPAL Rev 2009(98):83-101

Grigorian D A, Kryshko M (2017) "Deposit insurance, remittances, and dollarization: survey-based evidence from a top remittance-Reveiving country" IMF working Paper (WP/17/132)

Gujarati D, Porter DC (2009) Basic Econometrics,5th edition. McGraw Hill

Hall RE (1978) Stochastic implications of the life cycle-permanent income hypothesis: theory and evidence. J Polit Econ 86:971-987

Hall RE, Mishkin FS (1982) The sensitivity of consumption to transitory income: estimates from panel data on households. Economica 50(2)

Hausman JA (1998) Specification tests in econometrics. Econometrica 46:1251-1272

Hayashi F (1982) The permanent income hypothesis: estimation and testing by instrumental variables. J Polit Econ 90:895-916

Holmes JM (1974) A test of the permanent-income hypothesis: comment. J Polit Econ 82:185-191

Inter-American Development Bank (2009) Remittances to LAC in 2009: the impact of global recession Washington DC

International Debt Statistics (2014) World Bank

International Financial Statistics Yearbook (2012) IMF Washington DC 
International Financial Statistics Yearbook (2015) International Monetary Fund

International Financial Statistics Yearbook (2016) IMF Washington DC

International Monetary Fund (2009) The implications of the global financial crisis for low-income countriesan update, Washington DC, September 28

International Monetary Fund (2010) Balance of Payments Manual, 6th edition

Kmenta J (1986) Elements of econometrics, $2^{\text {nd }}$ ed. McMillan, New York

Kreinin M (1961) Windfall income and consumption- additional evidence American Economic Review,

Kreuger D, Perri F (2008) How does household consumption respond to income shocks? NBER,

Laumas PS (1969) A test of the permanent income hypothesis. J Polit Econ 77:857-861

Levin A, Lin CF, Chu C (2002) Unit root tests in panel data: asymptotic and finite-sample properties. J Econ 108:1-24

Lucas R (1976) Economic Policy Evaluation: A Critique. In The Phillips Curve and Labor Markets, ed by K. Brunner and A. H. Meltzer, North- Holland, Amesterdam

Lueth E, Ruiz-Arranz M (2006) A gravity model of workers' remittances. IMF Working Paper International Monetary Fund

Migration and Development Brief \# 24 (2015), World Bank

Migration and Remittances Factbook (2011) Second edition. World Bank

Mishra P (2007) Emigration and wages in source countries: evidence from Mexico. J Dev Econ 82(1):180-199

Modigliani F (1976) Life-cycle, individual thrift, and the wealth of nations. Am Econ Rev 76(3):297-313

Multilateral Investment Fund (2006) The potential impact of Remittances on the Regional Economy of LAC.April

Neagu I. C, Schiff M (2009) Remittance stability, cyclicality and stabilizing impact in developing countries. Policy research working paper. The World Bank

OECD (2006) International Migration Remittances and their Role in Development International Migration Outlook

Ratha D (2007). Leverage remittances for development. Migration Policy Institute Policy Brief

Ratha D, De S, Devisevic E. (2015) "Migration and Development Brief 24". Washington, DC: World Bank

Ratha D, Mohapatra S, Silwal A (2011) "Migration and Development Brief 17". Washington, DC: World Bank

Spatafora N (2005) Two Current Issues Facing Developing Countries In world economic outlook: A survey by the staff of the International Monetary Fund. Chapter Two

UNCTAD (2010) Maximizing the development impact of remittances United Nations

UNCTAD (2011) Impact of remittances on poverty in developing countries, United Nations

United Nations (2015) Sustainable development goals, New York

Willassen Y (1978) An analysis of the effect of transitory income on consumption. Scand J Econ 80(3):299-310

World Bank (2006a) Economic implications of remittances and migration, Global Economic Prospects

World Bank (2006b) International migration remittances and their role in development. International Migration Outlook, 139-161

Yang D (2004) "International Migration, Human Capital and Entrprenuership” World Bank Policy Research Working Paper no. 3578

Yang D (2006) Coping with Disaster: The Impact of Hurricanes on International Financial Flows, 1970-2001 (Mimeo, University of Michigan, Ann Arbor)

Yang D, Choi H (2007) Are remittances insurance? Evidence from rainfall shocks in the Philippines. World Bank Econ Rev 21(2):219-248 